\title{
Public Speaking in Islamic High School: Practical Steps on Islamic Civilization Topics
}

\author{
Rafika Rabba Farah ${ }^{1}$, Puji Sumarsono ${ }^{2}$, Alimin Adi Waloyo ${ }^{3}$ \\ Universitas Muhammadiyah Malang \\ email: ${ }^{1}$ rafikafarah@gmail.com
}

\begin{abstract}
The tenet of being able to speak English in public sphere as a global life skill has now been a driving force for many Indonesians to learn English since early age. Not only in educational sector, public speaking skill is also in high demand for nowadays' context-industrial marketplace era. Yet, in many situations, teachers fail to support students with the necessary skills to perform public speaking. As English is still a foreign language in Indonesia, assigning students to perform public speaking without proper training leads into fear or anxiety. However, a practical training into what the best practices of public speaking should be undertaken by educators. Moreover, Indonesia as the biggest Muslim country has many Islamic schools around. For Islamic high school students, Islamic-based material is the content that likely becomes the discourse of the school curriculum. To preach Islam in a global level, English can open up ways to this. Thus, the notion of infusing Islamic-based content in public speaking classroom is necessary. Implementing this, a training on Public Speaking with Islamic-based materials were conducted in Madrasah Aliyah Muhammadiyah 1 Malang Indonesia through Experienced-based Learning method. The study results in highlighting several practical steps for Public Speaking with Islamic Civilization content. Procedures will highlight on experienced-based learning and some techniques to support a local-based atmosphere. In so doing, this present study suggests that Islamic Civilization content can be used as a supporting material for students learning in Islamic school context. Therefore, it is recommended that teachers in Islamic school can design the curriculum that underlies Islamic elements.

Keywords: Islamic Civilization, Public Speaking, Islamic High School

\begin{tabular}{|c|c|c|}
\hline $\begin{array}{c}\text { First Receive: } \\
\text { 19 October 2019 }\end{array}$ & $\begin{array}{c}\text { Revised: } \\
\text { 4 November 2019 }\end{array}$ & $\begin{array}{c}\text { Accepted: } \\
\text { 28 November 2019 }\end{array}$ \\
\hline $\begin{array}{c}\text { Final Proof Recieved: } \\
\text { 1 December 2019 }\end{array}$ & Published: \\
\hline \multicolumn{3}{|c|}{ How to cite (in APA style): } \\
$\begin{array}{c}\text { Farah, R. R., Sumarsono, P., \& Waloyo, A. A. (2019). Public Speaking in Islamic High } \\
\text { School: Practical Steps on Islamic Civilization Topics. Schemata, 1 (2), 35-46 }\end{array}$ \\
\hline
\end{tabular}
\end{abstract}

\section{INTRODUCTION}

Teachers who are involved in speaking course design have spent considerable amount of time and energy theorizing, analysing, and researching the course stream of its syllabus. As known by many, in advanced level, public speaking has been the prominent skills indicating students' success in speaking class. The information suggests that the success of making public speaking during high school will affect students' future life either in academic, for their university life, or non-academic setting-leading the society.

Numbers of researchers in communication fields have discussed about students' anxiety to speak before the public. For example, a research to 815 students at Midwestern 
Farah, R. R., Sumarsono, P., \& Waloyo, A. A, Public Speaking in Islamic High School: Practical Steps...

University in the U.S about fear shows that the top rank was speaking in front of a group of people, comes after it fear to death ${ }^{39}$. The study concludes that fear of speaking in front of public has been associated closely to fear of death. A study at Omar Al-Mukhtar University in Libya revealed that age has a positive correlation to public speaking anxietythe younger the student is, the higher oral anxiety he/she has ${ }^{40}$. The explanation for this is that students do understand the language yet feeling difficult expressing it mainly are afraid of making mistakes. Likewise, another research revealed that there are three instrumental reasons that EFL students in Indonesian context are anxious for their oral skill. The anxiety are mainly triggered because of fear, shyness, and discomfort ${ }^{41}$. In the aspect of cognitive learning difficulties, EFL Students in Taiwan are found to have difficulties in voice variation, organizing and outlining speech body, explaining visual aids, gestures, postures, eye contact, preparing effective visual aids, and closing the speech, while the easiest part was opening the speech $^{42}$. The previous researches inferred that students' constraint for public speaking was more to psychological aspects, age, and incapability of organizing public speaking sequences.

Afterwards, the discussion on how to improve students' public speaking skill on psychological aspect and rhetoric are underlined. In terms of improving students' motivation to learn English in EFL context, a study shows that the familiarity of local wisdom provides a room for students to have a sense of belonging towards national honour, psychological domain, and territorial aspect ${ }^{43}$. Adapting TED talk sequences with Islamic content, students of Islamic Communication Departments at Sekolah Tinggi Ilmu Dakwah Surabaya Indonesia shows to have a more organized and powerful public speaking, mainly on their fluency and accuracy ${ }^{44}$. The studies have shed a light that Islamic schools can infuse Islamic content for public speaking performance.

39 Dwyer, K. K., \& Davidson, M. M. (2012). Is public speaking really more feared than death?. Communication Research Reports, 29(2), 99-107.

40 Gaibani, A., \& Elmenfi, F. (2016). Age as an Affective Factor in Influencing Public Speaking Anxiety of English Language Learners at Omar Al-Mukhtar University. Advances in Language and Literary Studies, 7(2), 179-182.

${ }^{41}$ Anandari, C. L. (2015). Indonesian EFL Students' Anxiety in Speech Production: Possible Causes and Remedy. TEFLIN Journal, 26(1), 1-16.

42 Lee, Y. J. J., \& Liang, J. C. (2012). Using video technology to diagnose EFL students' cognitive learning difficulties in public speaking. Procedia-Social and Behavioral Sciences, 64, 671-680.

${ }^{43}$ Muslim, A. B. (2017). Heritage narratives, motivation to learn English and the development of national identity: An Indonesian perspective. The Journal of Asia TEFL, 14(3), 414-429.

${ }^{44}$ Kusuma, L. A. (2017). Islamic-Content-TED Public Speaking as a Source Material for Improving Islamic Student's Communication Skill. JEES (Journal of English Educators Society), 2(2), 75-90.

\section{Copyright (c) 2019 Schemata Journal}

Available online at http://journal.uinmataram.ac.id/index.php/schemata 
Farah, R. R., Sumarsono, P., \& Waloyo, A. A, Public Speaking in Islamic High School: Practical Steps...

The reason of emphasizing on the importance of Islamic content in Islamic school context has been marked by some researches. English teaching has long been critiqued pedagogically by the inner circles, the non-Christian scholars such as ${ }^{45} 46 \quad 474849$ have pinpointed that English is a language that brings Christian message in its English teaching. Furthermore, English has its link to American and British culture (Holliday, 2009). In contrast, there is also an expert asserts that language and culture are tightly bound, it is to underline that language is not a stand-alone aspect-there should go together with context (culture $^{50}$. The two notions presented previously are not away to put the two ideas into a clash-it is merely that in Islamic worldview, Muslims have their own way of understanding a fundamental issue. In particular, Islamic school curriculum is adjusted in accordance to its context.

However, of the many studies on public speaking, a research on training for public speaking skills that focus on Islamic high school students by infusing Islamic content is still fairly limited, whilst there are numbers of Islamic schools existed in Indonesia. Thus, this study aims at giving some practical steps on how public speaking with Islamic elements are contextualized.

\section{RESEARCH METHOD}

Experience-based learning was implemented in the study. This method emphasize more on giving students experience to learning and teaching. The key element to this is that learners look at their experience through reflection and evaluation of prior experience so thus learners will draw meaning ${ }^{51}$. In this context, the public speaking training was taken place at Madrasah Aliyah Muhammadiyah 1 Malang Indonesia. The students involved in

45 Edge, J. (2003). Imperial troopers and servants of the Lord: A vision of TESOL for the 21st century. Tesol Quarterly, 37(4), 701-709.

${ }^{46}$ Pennycook, A., \& Coutand-Marin, S. (2003). Teaching English as a missionary language. Discourse: Studies in the cultural politics of education, 24(3), 337-353.

47 Makoni, S., \& Pennycook, A. (2005). Disinventing and (re) constituting languages. Critical Inquiry in Language Studies: An International Journal, 2(3), 137-156.

48 Pennycook, A. (2007). ELT and colonialism. In International handbook of English language teaching (pp. 13-24). Springer, Boston, MA.

49 Varghese, M. M., \& Johnston, B. (2007). Evangelical Christians and English language teaching. Tesol quarterly, 41(1), 5-31.

${ }^{50}$ Kramsch, Claire. 2013.Culture in foreign language teaching. Iranian Journal of Language Teaching Research 1, no. 1 (2013): 57-78.

51 Foley, G. (1995). Understanding adult education and training. Paul \& Company, c/o PCS Data Processing, Inc., 360 West 31 Street, New York, NY 10001. 
Farah, R. R., Sumarsono, P., \& Waloyo, A. A, Public Speaking in Islamic High School: Practical Steps...

training were 20. Some procedures taken were: 1) Preparing; 2) Modelling; 3) Practicing; and 4) Giving Feedback; 5) Reflecting. There were three sessions given for students to practice their skills and they were grouped into 6 to 7 students each. Each group assigned to practice public speaking into different roles, such as to be an MC (1 student), reciter of the Qur'an and its English translation (1 student), public speaker of a speech (4 students), and audiences ( 2 students). The activity lasted for 60 minutes each group. Through interaction with other peers, students can construct their own learning experience driven by social, cultural, and socio-emotional context.

\section{FINDING AND DISCUSSION}

Drawing upon the training given to learners, there are several practical step can be highlighted in this study.

Practical Steps

\section{Preparation Step}

\section{a. Group Division}

In this phase, students are divided into several roles: to be an $\mathrm{MC}$, to be a public speaker, and reciter of holy Qur'an and its English translation.

\section{b. Research}

In this phase, students who are assigned as public speaker are to search for a topic under Islamic Civilization, such as Five Pillars of Islam, Oneness of Allah, Islamic Manners, and Islamic History, Muslim Scholars, Islamic Law, etc. Furthermore, during this phase, students have to support their argument based on Islamic knowledge convention, it is to quote verse of the Qur'an and Hadith (the sayings of the Prophet Muhammad peace be upon Him). Thus, the quotation can help students anticipating for audiences' question and feedback later in the end of speech session. In the end of this phase, students are to prepare a speech script and hand it over to their teacher.

\section{Modelling}

Three teachers do a modelling as 1) an MC and moderator, 2) public speaker, 3) presenter for talk show. Afterwards, students are to practice the same role in the following meetings based on their group.

\section{Public Speaking Practice}

In this practice, speakers are to express their knowledge about religious teaching based on their previous research and preparation. Following it up, a room for dialogue is given

\section{Copyright () 2019 Schemata Journal}

Available online at $\mathrm{http}: / /$ journal.uinmataram.ac.id/index.php/schemata 
Farah, R. R., Sumarsono, P., \& Waloyo, A. A, Public Speaking in Islamic High School: Practical Steps...

for the listeners about his/her friend's view. The dialogues in religious convention, in this case is Islam, are widely open as far as students can provide a theoretical background and analysis from the Qur'an or Hadith-as these two are the only authentic sources of arguments that Muslims refer to.

\section{Feedback}

In the end of the speech and dialogue, speakers are given feedback from either their peers (audience) and teacher. Peer feedback is given by distributing speaking rubrics before the public speaking session has begun. Last but not least, the speakers themselves are also given a chance to reflect on their own performance, particularly on the language used and content. This is done descriptively, simply by asking some questions to the speaker about their performances. This step seems simple but self-reflection can be very powerful.

\section{Reflection}

Having done with the practice, students are asked several questions confirming on what they have been performed for the whole session, mainly on their feeling towards their own performance, some challenges and solutions.

\section{Guidelines on Script Drafting}

1. Opening

To begin a speech, a speaker has to do the following procedures: Greeting audiences

To greet audiences, a speaker can say Assalamu'alaikum everyone or Good morning ladies and gentlemen, or such greetings. Smile and keep your eye contact. Rising intonation is suggested in this part.

\section{Praising God (Allab) and also Prophet Muhammad (peace be upon Him)}

First of all, praise and gratitude due to Allah subhaanahu wa ta'ala the truly source of peace, All-Powerful, the Almighty. The One who has given us mercy and blessing and only to Him we shall return later in the Judgment Day. Secondly, may shalawat and salam be to our Prophet Muhammad shallallabu alaybi wasallam the best example of all human beings. Surely, from his teaching and sunnah, we all know the authentic teaching of Islam, thus, our life today is under the guidance of Islam.

\section{Appreciation}

Thank you for having me today. I am here standing before you all would like to deliver a speech entitled ...

2. Developing body

\section{Copyright $\odot 2019$ Schemata Journal}

Available online at http://journal.uinmataram.ac.id/index.php/schemata 
Farah, R. R., Sumarsono, P., \& Waloyo, A. A, Public Speaking in Islamic High School: Practical Steps...

In this section, students develop the content of speech based on Islamic Civilization topics. Also, in Islamic convention, to quote the verse of Qur'an and Hadith is a must upon delivering a speech. Not to mention, a speaker has to address the audience occasionally, by saying such phrases: Dear brothers and sisters. Additionally, a speaker has to describe fact or scientific data as a way to convince their audience that his/her speech has a reference to a reliable source.

\section{Closing}

To close the speech, a speaker closes it by highlighting some important notes from the body and give some brief conclusion.

What is clear from the public speaking training with Islamic content here is that the learning opportunity given in the training. As drawn in the diagram below, the MC, speaker, audience have created their own room for learning under teacher's supervision. Everyone is involved in the learning activity. This diagram shows that the public speaking training using this form opens up for experience-based learning during the classroom activity.

Figure 1. The anatomy of public speaking training with Islamic content

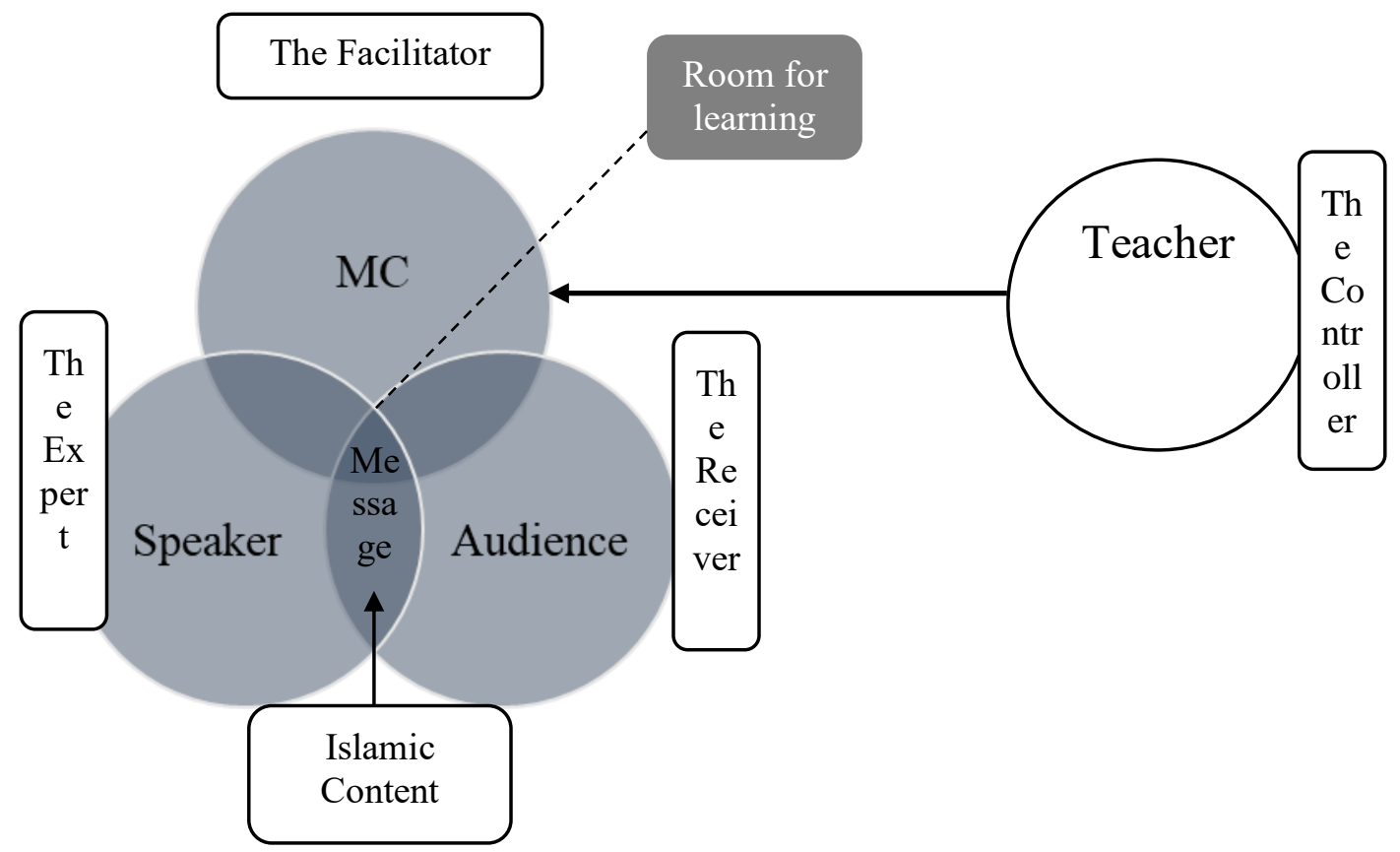

As it is stated, experience-based learning involves the whole class members to actively participate in the learning through games or roleplay, thus learner's intellect, 
Farah, R. R., Sumarsono, P., \& Waloyo, A. A, Public Speaking in Islamic High School: Practical Steps...

feeling, and sense are actually presented ${ }^{52}$. Furthermore, he highlights that the real learning occurs where personal experiences take place. The training given has presented a room where learners can actually engage in the learning with their peers through interaction, as drawn in the diagram, by involving their personal feeling, intelligence, and sensibility. The diagram has clearly shown that Islamic content which students are familiar with, has triggered learners to have further discussion. Therefore, the main feature of this training has indeed given emphasize on events in the learners' early life, current life, and future life-in which those features are the characteristic of experience-based learning.

Following the diagram, this study implies that teachers can adapt the anatomy so as to infuse Islamic elements on their teaching at Islamic school context. Thus, graduating from high school, students are expected to be able to preach the Islamic message to their surrounding also to the global citizens they interact with. For future research, this anatomy of public speaking can also be implemented through assigning students by vlogging activity, thus, the students' activity of vlogging will vary, not only focusing on 'trending topics' as known by many, but the Islamic Civilization topics will also be covered.

\section{CONCLUSION}

Public speaking training in Islamic school setting can involve Islamic civilization topics aiming at supporting learners' intellectual discourse as well as developing their Islamic knowledge competence. Experience-based learning is a method that can be implemented in the training as it gives learners' opportunity to get immersed with their personal experience to speak before the public. Thus, by involving intellectual, feeling, and sensibility, someone's learning can actually take place.

\section{ACKNOWLEDGEMENT}

The public speaking training was fully funded by Directorate of Research and Community Service (DPPM) University of Muhammadiyah Malang.

\section{REFERENCE}

Anandari, C. L. (2015). Indonesian EFL Students' Anxiety in Speech Production: Possible Causes and Remedy. TEFLIN Journal, 26(1), 1-16.

52 Foley, G. (1995). Understanding adult education and training. Paul \& Company, c/o PCS Data Processing, Inc., 360 West 31 Street, New York, NY 10001. 
Farah, R. R., Sumarsono, P., \& Waloyo, A. A, Public Speaking in Islamic High School: Practical Steps...

Dwyer, K. K., \& Davidson, M. M. (2012). Is public speaking really more feared than death?. Communication Research Reports, 29(2), 99-107.

Edge, J. (2003). Imperial troopers and servants of the Lord: A vision of TESOL for the 21st century. Tesol Quarterly, 37(4), 701-709.

Foley, G. (1995). Understanding adult education and training. Paul \& Company, c/o PCS Data Processing, Inc., 360 West 31 Street, New York, NY 10001.

Gaibani, A., \& Elmenfi, F. (2016). Age as an Affective Factor in Influencing Public Speaking Anxiety of English Language Learners at Omar Al-Mukhtar University. Advances in Language and Literary Studies, 7(2), 179-182.

Holliday, A. (2009). The role of culture in English language education: Key challenges. Language and intercultural communication, 9(3), 144-155.

Kramsch, Claire. 2013.Culture in foreign language teaching. Iranian Journal of Language Teaching Research 1, no. 1 (2013): 57-78.

Kusuma, L. A. (2017). Islamic-Content-TED Public Speaking as a Source Material for Improving Islamic Student's Communication Skill. JEES Journal of English Educators Society), 2(2), 75-90.

Lee, Y. J. J., \& Liang, J. C. (2012). Using video technology to diagnose EFL students' cognitive learning difficulties in public speaking. Procedia-Social and Behavioral Sciences, 64, 671-680.

Makoni, S., \& Pennycook, A. (2005). Disinventing and (re) constituting languages. Critical Inquiry in Language Studies: An International Journal, 2(3), 137-156.

Muslim, A. B. (2017). Heritage narratives, motivation to learn English and the development of national identity: An Indonesian perspective. The Journal of Asia TEFL, 14(3), 414-429.

Pennycook, A. (2007). ELT and colonialism. In International handbook of English language teaching (pp. 13-24). Springer, Boston, MA.

Pennycook, A., \& Coutand-Marin, S. (2003). Teaching English as a missionary language. Discourse: Studies in the cultural politics of education, 24(3), 337-353.

Varghese, M. M., \& Johnston, B. (2007). Evangelical Christians and English language teaching. Tesol quarterly, 41(1), 5-31. 